Lana Štefulj, mag. paed.

lana.stefulj@gmail.com

doc. dr. sc. Barbara Kušević

Filozofski fakultet Sveučilišta u Zagrebu

Odsjek za pedagogiju

bkusevic@ffzg.hr

\title{
SURADNJA OBITELJI, ŠKOLE I LOKALNE ZAJEDNICE - PEDAGOZI U DOUBLE BINDU
}

Sažetak: Apostrofiranje važnosti suradnje s lokalnom zajednicom recentan je i u domaćemu znanstvenom prostoru relativno neistražen oblik pozicioniranja odnosa obitelji $i$ škole u širemu egzosustavu i makrosustavu unutar kojih se taj odnos razvija. Cilj je ovoga rada analizirati kontradiktorna očekivanja kojima su pedagozi u procesu suradnje obitelji, škole i lokalne zajednice izloženi. Konkretnije, nakon analize nesklada između teorijskih i zakonskih artikulacija suradnje s lokalnom zajednicom i praktičnih ograničenja koja se u implementaciji tih artikulacija javljaju, u radu se razmatra odgovornost pedagoga za prepoznavanje specifičnih potreba obitelji u suradnji s lokalnom zajednicom spram sanacijsko-deficitnoga percipiranja obitelji koje je pritom lako demonstrirati, kao i imperativnost teorijskih zahtjeva za tijesnim povezivanjem obitelji, škole i lokalne zajednice spram menadžersko-koordinacijske uloge koju pedagozi pritom, uslijed kontekstualnih ograničenja, mogu preuzeti na sebe. Zaključni dio rada nudi smjernice za daljnje istraživanje ove teme.

Ključne riječi: paradigma sanacije, partnerstvo obitelji i odgojno-obrazovne ustanove, pedagoška profesija, tehnokratski pristup obrazovanju, teorija preklapajućih sfera utjecaja

\section{UVOD}

Počevši od Plowdenskoga izvještaja u šezdesetima (HMSO, 1967 prema Crozier, 1998) i Warnockova izvještaja u sedamdesetima (Feiler, 2010), odnos obitelji i škole već je nekoliko desetljeća predmetom interesa inozemnih i domaćih znanstvenika, uz golem broj pratećih teorijskih radova, sustavnih pregleda (Henderson i Berla, 1994; Henderson i Mapp, 2002), metaanaliza 
(Jeynes, 2007, 2015) i kišobran-analiza (Higgins i Katsipataki, 2015), koji u svojoj ukupnosti podupiru ideju važnosti intenzivnoga prožimanja tih dviju za dijete bazičnih domena. Pod utjecajem Bronfenbrennerova (1977) ekološkoga modela počelo se uviđati da su odnosi obitelji i škole duboko uronjeni u mrežu drugih kompleksnih odnosa, počevši od onih determiniranih karakteristikama neposrednih okruženja u kojima postoje, poput susjedstva i lokalne zajednice, pa sve do otisaka širega društvenog sustava i vremena u kojemu se razvijaju. Ovaj model stalno je mjesto brojnih rasprava o odnosima obitelji i odgojno-obrazovne ustanove (v. npr. sustavnu razradu u Downer i Myers, 2010) i po srži je svoga razumijevanja djetetova razvoja kompatibilan s Epsteininim (1992, 1995) modelom preklapajućih sfera utjecaja, jednim od najkorištenijih modela suradnje obitelji i odgojno-obrazovne ustanove uopće (Mattingly i sur., 2002, prema Daniel, 2011). Preklapajući moment Epsteininina modela referira se na odnose obitelji, škole i lokalne zajednice, pri čemu je u središtu preklapanja upravo dijete, koje ima bolji kontekst razvoja ako je preklapanje između triju sfera veće (Daniel, 2011).

Epstein, međutim, model nije krenula razvijati kao model triju preklapajućih sfera utjecaja: u tekstu iz 1992. autorica, doduše, već ističe važnost zajednice, ali navodi kako je u ranijim radovima analizirala pet osnovnih tipova roditeljske uključenosti (Epstein, 1987b, prema Epstein, 1992), kojima je potom dodala šesti tip, koji prepoznaje utjecaj zajednice (Epstein, 1992), da bi u kasnijim radovima već u naslovima radova redovito isticala i zajednicu (npr. Epstein, 1995, 1996, 2018). Autorica pojašnjava da dodavanje zajednice kao treće preklapajuće sfere utjecaja otvara nov istraživački prostor, koji bi trebao odgovoriti na pitanje ,je li riječ o zasebnome tipu uključenosti i, ako jest, kako se razlikuje od ostalih. Primjerice, škola-zajednica, obitelj-zajednica i škola-obitelj-zajednica odnosi mogu imati odvojene i kombinirane učinke na djetetovo učenje. Ili, grupe i individue iz zajednice mogu osigurati resurse koji jačaju ostalih pet tipova odnosa između škole i obitelji.““ (Epstein, 1992, str. 14). Čini se kako je u tome inicijalnom artikuliranju revidiranoga modela autorica iznijela dvojbu je li zajednica moderator svih ostalih dimenzija roditeljske uključenosti (primjerice, učenja kod kuće ili komunikacije sa školom) ili sadržajno odvojena, od ostalih bitno različita domena. Zajednicu, u kojoj prepoznaje ulogu različitih agencija, kulturnih, poslovnih i drugih organizacija i sl., vidi bitnim utjecajem na dijete, a škole onima koje omogućavaju ili koordiniraju pristup obitelji resursima iz zajednice (Epstein, 1992), ističući da bliski odnos između navedenih domena povećava vjerojatnost da će učenici dobivati istoznačne poruke o važnosti obrazovanja (Epstein, 2010). U ovome, šestom, tipu roditeljske uključenosti cilj je ,identificirati i integrirati resurse i usluge iz zajednice kako bi se ojačali školski programi, obiteljske prakse i učenikovo učenje i razvoj“ (Epstein, 2010, str. 85) pa se škole povezuju s različitim sudionicima iz zajednice koji su zainteresirani i odgovorni za obrazovanje djece 
(Epstein, 1992; Sanders, 2001, sve prema Epstein i Sanders, 2002), a obitelji se informiraju o programima i uslugama u zajednici, pri čemu se nastoji olakšati njihov pristup istima (Epstein i Sanders, 2002). Također, izdvaja se mogućnost da škole suradnjom sa zajednicom unaprijede kvalitetu vlastitih programa, a istovremeno se prepoznaje i uloga roditelja kao važnih aktera suradnje (Epstein i Sanders, 2002).

Na tragu opisane Epsteinine (1992) dvojbe, u ovome radu istovremeno prepoznajemo i moderirajući učinak lokalne zajednice na sve oblike interakcija između obitelji i škole i zasebnost/sadržajnu specifičnost te domene suradnje. Pritom na prvu liniju promišljanja stavljamo odnos obitelji i škole, u koji se potom uključuje i lokalna zajednica, shvaćena kao ukupnost programa, aktivnosti, socijalnih poticaja i obrazovnih prilika koje postoje u obitelji i školi bliskome okruženju jer je u fokusu ovoga rada uloga pedagoga, koji je zastupnik primarno djeteta, a potom i svoje ustanove, čime ne impliciramo da obitelj i zajednica ne bi mogle/trebale njegovati zasebne, o odgojno-obrazovnoj ustanovi neovisne odnose. Na tragu takva razumijevanja odnosa ovih triju domena, kao i na tragu određenja suradnje obitelji i škole koje nude Bartulović i Kušević (2016), suradnju obitelji, škole i lokalne zajednice u ovome radu određujemo kao proces stalne razmjene informacija, prilika i iskustava između članova obitelji, škole i lokalne zajednice, usmjeren na podupiranje djetetova obrazovnoga potencijala, a u kojemu primarnu kohezivnu ulogu uglavnom ima odgojno-obrazovna ustanova. U nastavku rada analiziramo suradnju obitelji, škole i lokalne zajednice u domaćemu kontekstu.

\section{SURADNJA OBITELJI, ŠKOLE I LOKALNE ZAJEDNICE U REPUBLICI HRVATSKOJ}

Odnos obitelji, škole i lokalne zajednice u domaćemu znanstvenom prostoru na teorijskoj razini opsežnije adresira Ljubetić (2014) u monografiji Od suradnje do partnerstva obitelji, odgojno-obrazovne ustanove i zajednice, u kojoj analizira model angažirane zajednice autorice McDermot (2008, prema Ljubetić, 2014, str. 121), usmjeren na „obrazovanje i osnaživanje roditelja i profesionalaca koji rade s roditeljima i njihovo usmjeravanje na širi kontekst te pronalaženje putova kojima mogu zajednički unaprijediti zajednicu na dobrobit djece“, kao i potporu društvene zajednice obitelji i roditeljstvu u Hrvatskoj (Ljubetić, 2014), iz čega je razvidno autoričino usmjeravanje ne samo na potrebe obitelji i stručnjaka u odgojno-obrazovnim ustanovama već i na dobrobit zajednice u cjelini. Nadalje, u uvodu u svoje empirijsko istraživanje Kranželić i Ferić Šlehan (2008) ističu važnost partnerstva škole, obitelji i zajednice za dijete, ali i sve druge uključene strane (Ellis i Hughes, 2002, prema Kranželić i Ferić Šlehan, 2008), pri čemu se osobito usmjeravaju na spomenuti šesti Epsteinin model uključenosti roditelja naglašavajući empirijski 
dokumentiran veći uspjeh različitih preventivnih programa kada oni uključuju sustavni pristup problemu. Pišući o interkulturnome obrazovanju, Bartulović i Kušević (2016) analiziraju odnos škole i lokalne zajednice, tek ovlaš spominjući mogućnost da se u taj odnos uključe i obitelji. Što se empirijskih istraživanja tiče, Štefulj (2021) donosi pregled malobrojnih koji su se bavili istraživanjem uključenosti roditelja u suradnju sa školom i lokalnom zajednicom, a činjenica da se u većini istraživanja suradnja s lokalnom zajednicom zapravo nalazi na marginama interesa, a ne u fokusu, upućuje na to da je više riječ o korištenju progresivne terminologije no stvarnome istraživačkom interesu za tu temu.

Valja postaviti pitanje zbog čega se tema odnosa obitelji, škole i lokalne zajednice čini ostavljenom na marginama domaćih razmatranja - je li pritom riječ o malome broju znanstvenika koji se inače bave odnosom obitelji i škole, pri čemu je onda izostavljanje lokalne zajednice kao „dodatnoga“ aktera u ionako kompleksnome i nedostatno kontekstualno istraženome dijadnom odnosu očekivano ili je riječ o specifičnim obilježjima domaćega makrokonteksta, koja od ove teme udaljavaju i praktičare i znanstvenike? Bronfenbrenner (1977) makrosustav opisuje kao opće kulturne otiske u ekonomskome, društvenome, obrazovnome, pravnome i političkome smislu, koji se onda reflektiraju na sve niže razine sustava. U tome nam se smislu dio odgovora na postavljeno pitanje čini opravdanim tražiti upravo u nekoliko čimbenika makrosustava, kao što su općenita pozicioniranost lokalne zajednice u hrvatskome društvu, kodificiranost pedagoške profesije, legislativno određenje rada stručnih suradnika u školi i sl. Pritom osobito važnim otiskom makrokonteksta vidimo upravo način na koji je u relevantnim dokumentima opisana profesionalna uloga pedagoga i drugih stručnih suradnika u školama. U Pravilniku o tjednim radnim obvezama učitelja i stručnih suradnika u osnovnoj školi (2014, čl. 20) kao jedna od obveza pedagoga, uz suradnju s roditeljima, prilično se općenito spominje da on „surađuje s ustanovama“, q Nacionalni kurikulum za osnovnoškolski odgoj i obrazovanje (2017, str. 31), odmah ispod opisa uloge pedagoga, ističe kako ,[š]kola treba omogućiti suradnju s roditeljima, lokalnom i širom zajednicom kako bi se ostvarilo poticajno i pozitivno okruženje. (...) Šira i lokalna zajednica pružaju učenicima i učiteljima različite mogućnosti za suradnju u građanskome aktivizmu, volonterstvu, kulturno-umjetničkim događanjima te uzajamno pomaganje u organizaciji različitih aktivnosti važnih za lokalnu i širu zajednicu. Lokalna zajednica, roditelji i škola potiču suradnju učenika i učitelja na regionalnim, nacionalnim i međunarodnim projektima.“, što upućuje na činjenicu da ovaj dokument prati ranije opisan teorijski diskurs i odnos obitelji, škole i zajednice vidi kao međusobno ispreplićući.

Međutim, za takvo je djelovanje pedagoga/škole nužno osigurati i potrebne resurse, vremenske prije svega. U zborniku Suvremeni izazovi u radu (školskog) pedagoga (Turk, 2017) prikazano je nekoliko manjih empirijskih istraživanja 
koja postavljaju obrise razumijevanja i prakticiranja uloge pedagoga na ovim prostorima, a za temu ovoga rada zanimljivo je istraživanje Vračar i Maksimović (2017, isticanje naše) provedeno u Srbiji s 51 pedagogom-stručnim suradnikom, kojim su se željele ustvrditi profesionalne aktivnosti školskih pedagoga, a čiji su rezultati pokazali da je aktivnost na koju najveći broj školskih pedagoga troši najmanji dio svojega radnog vremena upravo suradnja s lokalnom zajednicom (operacionalizirana odvojeno od rada s roditeljima). Drugim za temu relevantnim istraživanjem, u kojemu su podatci prikupljeni samoprocjenom 91 školskog pedagoga, Popović i Anđelković (2017, isticanje naše) pokazale su da su od devet navedenih područja djelovanja pedagozi najmanje posvećeni suradnji s nadležnim ustanovama, organizacijama, udruženjima i jedinicom lokalne samouprave s jedne i radu s roditeljima s druge strane. Ovaj je nalaz također zanimljiv zato što upućuje na činjenicu da se suradnja s roditeljima i s lokalnom zajednicom držala dvaju odvojenih konstrukata, ali i zato što se oba konstrukta po učestalosti primjene nalaze na samome dnu profesionalnih nastojanja ispitanika, tragom čega autorice zaključuju da je takva pozicioniranost rada s roditeljima i lokalnom zajednicom, na kojemu suvremena teorija inzistira, zabrinjavajuća, ali i da ,[1]iteratura, iskustva školskih pedagoga i sama školska praksa upućuju na odvojenost teorijskih pristupa i preporuka od djelovanja pedagoga u svakodnevnom radu.“" (Popović i Anđelković, 2017, str. 292). Valja pritom imati na umu neadekvatnu ekipiranost stručnih timova određenih škola, koja otežava uočavanje osobe koja bi, ponad svih svojih zaduženja, bila odgovorna i za njegovanje odnosa obitelji, škole i lokalne zajednice. U istraživanju Velki i Ozdanovac (2014, str. 344), usmjerenome na preventivne programe smanjenja vršnjačkoga nasilja u osnovnim školama Osječko-baranjske županije, u koje je bilo uključeno 47 pedagoga i 18 psihologa, pokazalo se kako „neki stručni suradnici smatraju kako bi trebalo poboljšati suradnju s udrugama lokalne zajednice (policija, CZSS i dr.), bolje i češće educirati učitelje, djecu i roditelje, a kao problem u nekim školama javlja se i nedostatak ili manjak stručnih suradnika (psihologa, pedagoga i sl.).“

Ipak, u situaciji u kojoj pedagog u odgojno-obrazovnoj ustanovi postoji, smatramo opravdanim prepoznati ga kao ključnoga aktera u povezivanju ovih triju domena, kako ga primjerice prepoznaju i Bryan i sur. (2019), PažinIlakovac (2016) i Walsh i DePaul (2008). Polazeći stoga od opisane diskrepancije između teorijski artikuliranih očekivanja glede prepoznavanja zajednice kao bitnoga aktera suradnje obitelji i škole, koja nisu popraćena adekvatnim empirijskim dokumentiranjem stvarnoga stanja u praksi niti strukturalno-organizacijskim uvjetima u odgojno-obrazovnome sustavu koji bi podupirali praktičnu implementaciju tih teorijskih očekivanja, u nastavku se rada fokusiramo na kritičko razmatranje potencijalno kontradiktornih zahtjeva kojima su pedagozi u ovome aspektu svoje profesionalne uloge izloženi. 


\section{DOUBLE BIND PEDAGOGOVA DJELOVANJA U POVEZIVANJU OBITELJI, ŠKOLE I LOKALNE ZAJEDNICE}

Ranije opisan teorijski diskurs suradnju obitelji, škole i lokalne zajednice vidi kao integraciju resursa zajednice s ciljem osnaživanja školskih programa i obiteljskih praksa (Epstein, 1995), usvajanja pozitivnih stavova o školi i obrazovanju (Epstein, 2013), povećanja otpornosti učenika te poticanja njihova akademskoga, socioemocionalnoga i profesionalnoga razvoja (American School Counselor Association, 2012; Bryan i Henry, 2008, 2012, sve prema Bryan i sur., 2018). Kako je u prethodnome poglavlju opisano, Nacionalni kurikulum za osnovnoškolski odgoj i obrazovanje (2017), kao jedan od temeljnih prosvjetnih dokumenata u Republici Hrvatskoj, prati naprednost toga teorijskog diskursa, no progresivno razumijevanje mogućnosti odnosa obitelji, škole i zajednice nije preneseno u legislativu, gdje je u Zakonu o odgoju i obrazovanju u osnovnoj $i$ srednjoj školi (2008) suradnja škola s vanjskim sudionicima operacionalizirana suradnjom s ustanovama socijalne skrbi, zdravstvenim ustanovama i zavodima za zapošljavanje (čl. 57) te suradnjom s nadležnim institucijama u slučajevima pojave situacija koje to zahtijevaju (čl. 70). Sagledamo li zakon kao jedan od instrumenata konstrukcije pedagoške svakodnevice, ovako postavljen pravni okvir govori o reduciranome shvaćanju suradnje sa zajednicom, a površnim sagledavanjem mogućnosti suradnje, u slučajevima poput ovoga, zakonodavstvo može sputavati potencijale škola kao $\mathrm{k}$ transformaciji usmjerenih ustanova, kakvima ih razumije kritička pedagogija (Bartulović i Kušević, 2016).

Ovaj smo nesklad uočile u već spomenutome istraživanju prve autorice ovoga rada, u kojemu je uloga pedagoga u suradnji obitelji, škole i lokalne zajednice operacionalizirana preko elemenata proaktivnih i reaktivnih aktivnosti, gdje proaktivne uključuju, između ostaloga, izradu plana suradnje škole s lokalnom zajednicom, izradu informativnih sadržaja za obitelji o resursima u lokalnoj zajednici, uključivanje članova obitelji i lokalne zajednice u provedbu školskih programa i projekata, povezivanje s obrazovnim institucijama u programe mentorstva, povezivanje obitelji s resursima koji pružaju prilike za učenje i provedbu slobodnog vremena, organizaciju stručne i materijalne podrške za obitelji, informiranje članova obitelji o mogućnostima vlastita doprinosa lokalnoj zajednici, održavanje djelatnosti dionika lokalne zajednice u prostorima škole i razmjenu iskustava s drugim pedagozima u lokalnoj zajednici, a reaktivne podrazumijevaju uključivanje služba koje pružaju specijaliziranu podršku u radu s obiteljima, organizaciju posjeta domu obitelji i organizaciju materijalne pomoći za obitelji (Štefulj, 2021), pri čemu je empirijski dio istraživanja pokazao „da se reaktivno uključivanje lokalne zajednice u suradnju pedagoga s obiteljima problematizira češće $u$ odnosu na preventivno u odgovorima sudionica““ (Štefulj, 2021, str. 55). Uočljiva je, dakle, diskrepancija između shvaćanja 
suradnje obitelji, škole i zajednice kao prostora za doprinos napretku cjelokupnoga društva, čiji su obitelji i škole dio, u odnosu na legislativu i dobivene empirijske nalaze, koji su u velikoj mjeri usmjereni na uključivanje zajednice u odnos obitelji i škole u situacijama kada je obiteljsku dinamiku na neki način potrebno „,izmijeniti“ u suradnji s nadležnim institucijama. Postavlja se pitanje leži li razlog tomu u ograničenosti vremenskih kapaciteta školskih pedagoga, nedostatku materijalnih resursa za provedbu suradničkih aktivnosti, nedostatnoj pripremljenosti pedagoga za ovaj aspekt profesionalne uloge, $u$ inherentnome shvaćanju profesionalne uloge pedagoga kao dominantno korektivne u odnosu na učenike i njihove obitelji ili čemu drugom. Tijekom rada vraćat ćemo se nekima od ovih pretpostavaka kao plauzibilnim uzrocima detektiranih problema. Uočena nas je diskrepancija potaknula na promišljanje o svojevrsnome procijepu u kojemu se pedagozi u školama nalaze, a koji smo ovdje nazvale „,double bind" procijepom. Upotrebljavamo sintagmu double bind, nastalu u okviru psihoterapije, označavajući njome stanje u kojemu dvije poruke koje se pojedincu šalju produciraju određene paradokse i inkongruentnosti (Bateson i sur., 1963). Iako koncept psihoterapijske provenijencije, double bind danas se koristi kao referentni okvir za analizu kontradiktornih očekivanja u različitim ljudskim interakcijama, izvan područja u kojemu je inicijalno artikuliran. U nastavku rada analiziramo dvije točke prijepora u očekivanjima od pedagoga u suradnji obitelji, škole i lokalne zajednice.

Prva točka prijepora, na tragu uvoda u ovu temu, problematizira zakonima propisanu ulogu pedagoga u suradnji sa sudionicima iz lokalne zajednice, temeljem kojih moraju reagirati na uočene roditeljske propuste ili nedostatne resurse obitelji; međutim, fokus na to izlaže ih riziku promatranja obitelji iz modela deficita (Goodall, 2021 takvu promatranju vidi osobito izloženima siromašne roditelje). Zanimalo nas je postoji li, osim u legislativi, odrednica koja reaktivne aktivnosti jasnije propisuje, izvorište takva fokusa i u samome shvaćanju profesije pedagoga kao korektivno-sanacijske. Određena istraživanja daju uporište za daljnje promišljanje o toj tezi. Tako su Paulson i Edwards (1997) proveli istraživanje usmjereno na razumijevanje roditeljskih očekivanja od školskih savjetnika (profesija koja se može usporediti s onom pedagoga) u kanadskim školama, a njihovi su rezultati pokazali da sudionici smatraju važnima sposobnost savjetnika da identificira i rješava probleme kod učenika i obitelji, kao i da uputi roditelje na potrebne resurse te se u velikoj mjeri slažu da savjetnici trebaju obavljati navedene zadaće u svome radu. Istraživanje koje su provele Clark i Amatea (2004) proučavalo je percepcije i očekivanja američkih nastavnika od školskih savjetnika, pri čemu su sudionici prepoznali važnost uloge savjetnika $u$, između ostaloga, identificiranju i rješavanju nepovoljnih (obiteljskih) situacija i pružanju pomoći nastavnicima pri rješavanju problema. Za ovu su nam temu osobito važna istraživanja provedena u kontekstima koji poznaju profesiju pedagoga u tradiciji kontinentalne pedagogije. Rezultati 
istraživanja Žužić i Markušić (2017) o percepciji pedagoga iz perspektive srednjoškolskih učenika pokazali su tako da učenici pomoć u rješavanju problema vide kao jednu od važnih zadaća školskih pedagoga, a u kvalitativnome istraživanju usmjerenome na opis sličnosti i specifičnosti uloga pedagoga i psihologa Skopljak i sur. (2020) kao jednu ulogu pedagoga i psihologa prepoznaju njegovanje partnerskih odnosa sa svim dionicima u školi i izvan nje, no sudionici fokus grupa, pedagozi i psiholozi, smatrali su da su pedagozi više usmjereni na korektivni, a psiholozi na preventivni rad.

Iz rezultata navedenih istraživanja primjetno je da različiti subjekti odgojno-obrazovnoga procesa ulogu pedagoga povezuju s radom na detekciji i rješavanju problema. Iako to kako drugi pedagoga percipiraju ne mora značiti da se on upravo percipiranim aktivnostima dominantno bavi, kada bi dodatna empirijska istraživanja doista potvrdila njegovo profesionalno fokusiranje na detekciju poteškoća u suradnji s obiteljima i lokalnom zajednicom, pitamo se bi li se takav fokus mogao držati suštinski problematičnim, odnosno je li u srži pedagoške profesije doista inherentan naglasak na rješavanju problema ili je ona dominantno usmjerena, upravo suprotno, na horizont mogućnosti, odnosno na prepoznavanje točaka koje omogućuju podupiranje potencijala individua s kojima njegujemo pedagoške odnose. Amatea i sur. (2006), analizirajući različite zamke fokusa suradnje škole s obiteljima na patologiju, pitaju se koliko uopće konstruktivno može biti usmjeravati se na one aspekte obiteljskoga funkcioniranja koji su teško izmjenjivi (npr. siromaštvo ili obiteljsku strukturu) i posljedično traže usmjeravanje prema obiteljskim snagama koje mogu podržavati djetetov razvoj, a Zembylas (2020), pišući o kritici u obrazovanju i zamjerajući kritičkoj pedagogiji akcentiranje problema i kriza, ističe kako se negativna pozicija može čak držati antiobrazovnom, a alternativna, korištenje afirmativne kritike u obrazovanju, naglasak stavlja na ono što je u sadašnjemu trenutku dobro i pojedincima zajedničko (Hodgson i sur., 2017, prema Zembylas, 2020), pri čemu smatra da takav pristup ,potiče nastavnike i učenike u školama na korištenje afirmativnih praksi koje napuštaju binarnosti istinito/lažno, mi/oni, a koje perpetuiraju opozicije i animozitete“ (Zembylas, 2020, str. 12). Pritom autor ne tvrdi da takvo pozicioniranje primjećivanje problema čini neopravdanim, već nedostatnim, što držimo ključnim i za temu kojom se ovdje bavimo: balansiranje između ovih polariteta - s jedne strane pravovremeno uočiti izazove s kojima se obitelji suočavaju te adekvatno i promptno na njih odgovoriti profesionalnom podrškom, osobito imajući na umu da je sama profesija percipirana kao ona koja uočava i rješava probleme, no istovremeno ne dopustiti da prepoznavanje tih izazova bude osnovna pozicioniranost pedagoga u kontaktima s obiteljima i lokalnom zajednicom jer time biva spriječeno njegovanje skrbnih, na snagama i potencijalima baziranih odnosa - vidimo osobitim izazovom ne samo u kontekstu ove teme, već u radu pedagoga općenito (primjerice, s učenicima ili nastavnicima). 
Druga točka prijepora koju želimo opisati proizlazi iz činjenice da uloga pedagoga jest povezivanje obitelji, škole i lokalne zajednice, no svođenje te uloge na svojevrsno „menadžersko koordiniranje“ odnosa triju strana, jedino za što mnogi u svojemu rasporedu imaju vremena, pedagoge izlaže tehnokratskome konstruiranju vlastite profesije, gdje u performativnosti orijentiranome kontekstu nastoje maksimizirati povoljne učinke uz što manje uloženih resursa škole. U tu se diskrepanciju želimo uvesti promišljanjem o različitim načinima na koje bi se opisani raskorak između teorije i prakse suradnje obitelji, škole i lokalne zajednice hipotetski mogao pomiriti. Uzmemo li, zbog rastuće diversifikacije školskih, obiteljskih i lokalnih konteksta, smjer zatvaranja škole u odnosu prema obiteljima i lokalnim zajednicama malo vjerojatnim, u progrediranju odnosa obitelji, škole i lokalne zajednice izvjesnima nam se čine dva smjera. U prvome smjeru, koji držimo optimalnim, pedagog kao zastupnik prvenstveno učenika, a potom i institucije u kojoj djeluje, pristupa svojemu radu kao intelektualnoj aktivnosti uronjenoj u kulturni i društveni kontekst određene zajednice (Giroux, 1999). Povezivanje obitelji, škole i lokalne zajednice u takvu se kontekstu ne odvija kao odgovor na određene izolirane poticaje iz same lokalne zajednice ili reaktivne sanacije „problema u obitelji“, već iz viđenja vlastite uloge kao snažne intelektualne aktivnosti koja oblikuje „uvjete u kojima buduće generacije uče o sebi i o svojim odnosima s drugima i svijetom“ (Giroux, 1999, str. 147). Na tome je tragu zadatak pedagoga podržavanje kritičkoga, aktivnoga i transformativnoga odnošenja svih učenika i drugih aktera odgojno-obrazovnoga procesa prema svijetu čiji smo dio, a koji je prožet različitim odnosima interesa, moći, ali i međuovisnosti, koje škola u svojoj izolaciji ili dijadnoj komunikaciji s obitelji naprosto ne može zahvatiti. Isto tako, takvo je djelovanje legitimirano shvaćanjem roditeljevanja (i posljedično suradnje s obiteljima) kao snažno kontekstualno definirane aktivnosti (Belsky, 1984; Bronfenbrenner, 1977). Shvaćena tako, suradnja obitelji, škole i lokalne zajednice postaje ne teorijski progresivan dodatak koji pedagog treba pridodati ostalim elementima svojega rada, već jedini način na koji odnos obitelji i škole može biti pojmljen. Promatrati stoga što u lokalnoj zajednici postoji, a da može pomoći u boljemu razumijevanju svih subjekata odgojno-obrazovnoga procesa, inherentan je dio svakodnevne pedagoške aktivnosti.

Međutim, konstatiranje da je nešto inherentan dio pedagoške djelatnosti, bez uzimanja u obzir sustavne ograničenosti vremenskih, energijskih i drugih kapaciteta pedagoga, demonstriranje je određene razine kontekstualne neosviještenosti. Kao jednu preprjeku intenzivnijoj suradnji s drugim članovima stručnoga tima pedagozi i psiholozi u istraživanju Skopljak i sur. (2020) navodili su nedostatak vremena i opterećenost administrativnim poslovima, a i anegdotalna komunikacija autorica ovoga rada s pedagozima zaposlenima u školama upućuje na njihovu opterećenost raznim, nerijetko administrativnim, zadatcima koji se propulzivno umnažaju. U takvu kontekstu ne čudi okretanje 
menadžerskim kompetencijama koordiniranja, delegiranja i nadgledanja umjesto preuzimanja primarne odgovornosti za neku domenu. Giroux (1999, str. 144) na tome tragu piše kako poučavanje sve manje odgovara ranije opisanoj viziji intelektualne aktivnosti, a postaje sve više „depolitizirano, stručno osiromašeno činovništvo." Ovaj nam se smjer razvoja uloge pedagoga u odnosu obitelji, škole i lokalne zajednice, u kojemu bi pedagog bio tek sakupljač informacija i spona između različitih konteksta i pojedinaca, čini uslijed opisanih okolnosti izvjesnim, a vidimo ga kao dio šire tendencije organizacijske racionalizacije odgojno-obrazovnih sustava, usmjerene k osiguranju njihova učinkovitijega funkcioniranja (Mehta, 2013). Snažno kritizirajući ustrojavanje škola poput k učinkovitosti orijentiranih korporacija, Giroux (1999) također upozorava na opasnosti kojima su obrazovni sustavi koji ne raspolažu dovoljnim resursima izloženi, a to je opasnost gubljenja autonomije uslijed suradnje s korporativno orijentiranim akterima, što ih iz javnih sfera može transformirati u komercijalne. Naličje ovoga problema vidimo u tome što u tako shvaćenome odnosu obitelji, škole i lokalne zajednice, u kojemu pedagog menadžerski povezuje različite zainteresirane strane, korisnici usluge (tzv. „klijenti“") mogu postati i sami roditelji, što oblikuje plodan kontekst za reprodukciju društvenih nejednakosti, odnosno oblikovanje elitnih i neelitnih lokalnih okruženja. Jednako kao i prethodno detektirana diskrepancija, i ovaj jaz između adekvatnoga zadovoljavanja potreba obitelji, škole i lokalne zajednice uslijed ograničenih kontekstualnih uvjeta s jedne strane, a shvaćanja profesije pedagoga kao one koja se ne temelji na delegiranju i koordiniranju, već njegovanju autentičnih i intenzivnih pedagoških odnosa s različitim subjektima s druge strane, vidimo problemom koji nadmašuje temu ovoga rada i zadire u srž konstruiranja pedagoške profesije u uvjetima prodora neoliberalne logike u odgojno-obrazovni sustav.

\section{ZAKLJUČAK}

Temeljem u radu poduzete preliminarne analize prepoznajemo velik prostor za daljnje teorijsko i empirijsko istraživanje naslovne teme, koje bi doprinijelo boljemu razumijevanju toga kako školski pedagozi, pred koje se izvjesno stavljaju različita, u radu opisana, očekivanja, na takva očekivanja reagiraju i što njihove (re)akcije posljedično znače za shvaćanje uloge školskoga pedagoga kao jednoga od ključnih aktera u povezivanju obitelji, škole i lokalne zajednice. Navedene double bind situacije, koje prepoznajemo kao autentične dvojbe koje se mogu javiti u svakodnevnome radu pedagoga, nose sa sobom različite praktične implikacije. Pritom praktičari uslijed zahtjeva koji se pred njih stavljaju, poput, između ostaloga, rastuće količine administrativnih dužnosti, nedostatka vremena i orijentiranosti k racionalizaciji obrazovnoga procesa, mogu u kontekstu suradnje s obiteljima i zajednicom upasti u zamke deficitnoga 
promatranja obitelji, slijepoga praćenja legislative (koja u odnosu na teoriju vidno zaostaje i svodi odnos obitelj - škola - zajednica na uklanjanje poteškoća koje ometaju razvoj učenika) ili doživljavanja vlastite uloge kao dominantno organizacijske, čime se uloga pedagoga udaljava od one stručnjaka za unaprjeđivanje odgojno-obrazovnoga procesa, čiji su dio suradnja s obiteljima i zajednicom. Promišljajući holistički o temi rada, osobito zabrinjavajućim čini nam se opasnost svođenja pedagogove uloge na dvojaku apstrakciju: na upućivanje „nedovoljno funkcionalnih“ obitelji na različite institucijski oblikovane oblike „podrške" i unaprjeđivanja njihove funkcionalnosti s jedne strane i upućivanje „visoko funkcionalnih“ obitelji na različite resurse koje mogu dodatno utilizirati na korist svoje obitelji s druge strane. Ako tomu dodamo treću stranu, lokalnu zajednicu, koja bi u ovome odnosu mogla iskazivati određene ranije spomenute tržišno orijentirane interese, smatramo da suradnja s lokalnom zajednicom, ako nije pomno promišljena, u pedagoškome smislu može imati čak negativan učinak na transformativno djelovanje škola i inkluzivnu, pravednu filozofiju obrazovanja iako kao teorijska ideja nije tako zamišljena ni razvijana.

Prvim korakom $\mathrm{k}$ boljemu razumijevanju pozicioniranosti pedagoga $\mathrm{u}$ ovoj formi suradnje vidimo daljnje poduzimanje teorijskih i osobito empirijskih istraživanja u domaćemu kontekstu, pri čemu kao ključne sugovornike i sudionike istraživanja vidimo upravo pedagoge, koji mogu dati uvid u različite načine interpretiranja, prakticiranja i modificiranja vlastite profesionalne uloge u pokušaju povezivanja triju sfera utjecaja kojima je učenik izložen, no vrijedne priloge zasigurno bi ponudile i perspektive roditelja i različitih aktera iz različitih lokalnih zajednica. Naime, u radu smo konceptu zajednice prišle kao nacionalno homogenome i samorazumljivome, no uviđamo kako upravo različite lokalne zajednice mogu u velikoj mjeri moderirati kako će izgledati njihov odnos s obiteljima i školama. Takve bi nas spoznaje zasigurno približile odgovoru na pitanje kako odnos obitelji, škole i lokalne zajednice približiti idealu obitelji i škola uronjenih u kontekst u kojemu postoje, a koji omogućava svim akterima autentično življenje i međusobno podupiranje, udaljeno od logike nadgledanja i korekcije.

\section{LITERATURA}

1. Amatea, E. S., Smith-Adcock, S. i Villares, E. (2006). From Family Deficit to Family Strength: Viewing Families' Contributions to Children's Learning from a Family Resilience Perspective. Professional School Counseling, 9(3), 177-189.

2. Bartulović, M. i Kušević, B. (2016). Što je interkulturno obrazovanje? Priručnik za nastavnike i druge znatiželjnike. CMS. https://www.bib.irb.hr/869114

3. Bateson, G., Jackson, D. D., Haley, J. i Weakland, J. H. (1963). A Note on the Double Bind - 1962. Family process, 2(1), 154-161. https://doi. org/10.1111/j.1545-5300.1963.00154.x 
4. Belsky, J. (1984). The Determinants of Parenting: A Process Model. Child Development, 55(1), 83-96. https://doi.org/10.2307/1129836

5. Bogojević, H. (2017). Suradnja škole i obitelji kao bitan čimbenik odgoja i obrazovanja za održivi razvoj [diplomski rad, Sveučilište Jurja Dobrile u Puli]. https:// repozitorij.unipu.hr/islandora/object/unipu:1033

6. Brent, B. O. i Lunden, S. (2009). Much Ado About Very Little: The Benefits and Costs of School-Based Commercial Activities. Leadership and Policy in Schools, 8(3), 307-336. https://doi.org/10.1080/15700760802488619

7. Bristow, J. (2014). The Double Bind of Parenting Culture: Helicopter Parents and Cotton Wool Kids. U E. Lee, J. Bristow, C. Faircloth i J. Macvarish (ur.), Parenting culture studies (str. 200-215). Palgrave Macmillan. DOI 10.1057/9781137304612

8. Bronfenbrenner, U. (1977). Toward an Experimental Ecology of Human Development. American Psychologist, 32(7), 513-531. https://doi. org/10.1037/0003-066X.32.7.513

9. Bryan, J. A., Young, A., Griffin, D. i Holcomb-McCoy, C. (2018). Leadership Practices Linked to Involvement in School-Family-Community Partnerships: A National Study. Professional School Counseling, 21(1), 1-13. DOI:10.1177/2156759X18761897

10. Bryan, J., Griffin, D., Kim, J. Griffin, D. M. i Young, A. (2019). School Counselor Leadership in School-Family-Community Partnerships: An EquityFocused Partnership Process Model for Moving the Field Forward. U S. B. Sheldon i T. A. Turner-Vorbeck (ur.), The Wiley Handbook of Family, School, and Community Relationships in Education (str. 265-287). Wiley-Blackwell. DOI:10.1002/9781119083054

11. Clark, M. A. i Amatea, E. (2004). Teacher Perceptions and Expectations of School Counselor Contributions: Implications for Program Planning and Training. Professional School Counseling, 8(2), 132-140. https://www.researchgate.net/ publication/234675046_Teacher_Perceptions_and_Expectations_of_School Counselor_Contributions_Implications_for_Program_Planning_and_Training

12. Crozier, G. (1998). Parents and schools: partnership or surveillance? Journal of Education Policy, 13(1), 125-136. https://doi.org/10.1080/0268093980130108

13. Daniel, G. (2011). Family-school partnerships: towards sustainable pedagogical practice. Asia-Pacific Journal of Teacher Education, 39(2), 165-176. https://doi. org/10.1080/1359866X.2011.560651

14. Downer, J. T. i Myers, S. S. (2010). Application of a developmental/ecological model to family-school partnerships. U S. L. Christenson i A. L. Reschly (ur.), Handbook of School-Family Partnerships (str. 3-29). Routledge. https://doi. org/10.4324/9780203876046

15. Epstein, J. L. (2018). School, family, and community partnerships: Preparing educators and improving schools. Routledge. https://doi.org/10.4324/9780429494673

16. Epstein, J. L. (2013). Ready or Not? Why Future Educators Need a College Course on School, Family, and Community Partnerships. U B. Lucas (ur.), A Powerful 
Impact: The Importance of Engaging Parents, Families and Communitiesin Improving Student Success (str. 14-16). GEMS Education. https://learningfoundation.org.uk/wp-content/uploads/2016/03/GEMS-Parent-Engagement6604327.pdf

17. Epstein, J. L. (2010). School/Family/Community Partnerships: Caring for the children we share. Phi Delta Kappan, 92(3), 81-96. https://doi. org/10.1177/003172171009200326

18. Epstein, J. L. (1996). Advances in Family, Community, and School Partnerships. Community Education Journal, 23(3), 10-15. https://eric.ed.gov/?id=EJ538725

19. Epstein, J. L. (1995). School/Family/Community/ Partnerships: Caring for the Children We Share. Phi Delta Kappan, 76(9), 701-712. https://eric. ed.gov/?id=EJ502937

20. Epstein, J. L. (1992). School and Family Partnerships. Report No. 6. Center on Families, Communities, Schools and Children's Learning. https://eric. ed.gov/?id=ED343715

21. Epstein, J. L. i Sanders, M. G. (2002). Family, school, and community partnerships. U M. Bornstein (ur.), Handbook of parenting. Volume 5. (str. 407-437). Lawrence Erlbaum. DOI: 10.4324/9781410612137

22. Feiler,A. (2010). Engaging 'Hard to Reach'Parents. Teacher-Parent Collaboration to Promote Children's Learning. Wiley-Blackwell. DOI:10.1002/9780470684795

23. Geiger Zeman, M. i Zeman, Z. (2010). Uvod u sociologiju (održivih) zajednica. Institut društvenih znanosti Ivo Pilar. https://www.pilar.hr/wp-content/images/stories/dokumenti/e_knjige/uvod_u_sociologiju_zajednica.pdf

24. Giroux, H. A. (1999). Schools for Sale: Public Education, Corporate Culture, and the Citizen-Consumer. The Educational Forum, 63(2), 140-149. https://doi. org/10.1080/00131729908984404

25. Gitlin, A. (2000). The Double Bind of Teacher Education. Teaching Education, 11(1), 25-30. https://doi.org/10.1080/10476210050020336

26. Goodall, J. (2021). Parental engagement and deficit discourses: absolving the system and solving parents. Educational Review, 73(1), 98-110. https://doi.org/1 0.1080/00131911.2018.1559801

27. Henderson, A. T. i Berla, N. (ur.) (1994). A New Generation of Evidence: The Family is Critical to Student Achievement. National Comittee for Citizens in Education. https://eric.ed.gov/?id=ED375968

28. Henderson, A. T. i Mapp, K. L. (2002). A New Wave of Evidence: The Impact of School, Family, and Community Connections on Student Achievement. Annual Synthesis 2002. National Center for Family and Community Connections with Schools. https://eric.ed.gov/?id=ED474521

29. Higgins, S. i Katsipataki, M. (2015). Evidence from meta-analysis about parental involvement in education which supports their children's learning. Journal of children's services, 10(3), 280-290. https://doi.org/10.1108/JCS-02-2015-0009 
30. Jeynes, W. H. (2015). A Meta-Analysis: The Relationship Between Father Involvement and Student Academic Achievement. Urban Education, 50(4), 387423. https://doi.org/10.1177/0042085914525789

31. Jeynes, W. H. (2007). The Relationship Between Parental Involvement and Urban Secondary School Student Academic Achievement. A Meta-Analysis. Urban Education, 42(1), 82-110. https://doi.org/10.1177/0042085906293818

32. Kranželić, V. i Ferić Šlehan, M. (2008). Kvaliteta školskog okruženja u percepciji roditelja: temelj partnerstva škole-obitelji-zajednice. Kriminologija \& socijalna integracija: časopis za kriminologiju, penologiju i poremećaje u ponašanju, 16(2), 29-45. https://hrcak.srce.hr/99122

33. Ljubetić, M. (2014). Od suradnje do partnerstva obitelji, odgojno-obrazovne ustanove i zajednice. Element. https://www.bib.irb.hr/688647

34. Marincel, V. (2020). Izazovi inkluzije djece s teškoćama u redovitim osnovnoškolskim ustanovama iz perspektive pedagoga [diplomski rad, Filozofski fakultet Sveučilišta u Zagrebu]. https://repozitorij.ffzg.unizg.hr/islandora/object/ffzg:3483

35. Mehta, J. (2013). The Penetration of Technocratic Logic into the Educational Field: Rationalizing Schooling from the Progressives to the Present. Teachers College Record, 113(5), 1-40. https://dash.harvard.edu/handle/1/33063309

36. Nacionalni kurikulum za osnovnoškolski odgoj $i$ obrazovanje. Prijedlog nakon javne rasprave. (2017). Ministarstvo znanosti i obrazovanja. https://mzo. gov.hr/UserDocsImages//dokumenti/Obrazovanje/NacionalniKurikulum/ NacionalniKurikulumi//Nacionalni\%20kurikulum\%20za\%20osnovno\%C5\%A1kolski\%20odgoj\%20i\%20obrazovanje.pdf

37. Nacionalni okvirni kurikulum za predškolski odgoj i obrazovanje te opće obvezno i srednjoškolsko obrazovanje (2011). Ministarstvo znanosti, obrazovanja i športa RH. http://mzos.hr/datoteke/Nacionalni_okvirni_kurikulum.pdf

38. Pavić, Ž. i Vukelić, K. (2009). Socijalno podrijetlo i obrazovne nejednakosti: istraživanje na primjeru osječkih studenata i srednjoškolaca. Revija za sociologiju, 40(1-2), 53-70. https://hrcak.srce.hr/39824

39. Paulson, B. L. i Edwards, M. H. (1997). Parent Expectations of an Elementary School Counsellor: A Concept-Mapping Approach. Canadian Journal of Counselling, 31(1), 67-81. https://eric.ed.gov/?id=EJ553571

40. Pažin-Ilakovac, R. (2016). Kurikulumsko partnerstvo u izgradnji odgojno-socijalne kulture škole [doktorska disertacija, Filozofski fakultet u Osijeku]. https:// repozitorij.ffos.hr/islandora/object/ffos:1929

41. Popović, D. i Anđelković, A. (2017). Školski pedagozi o područjima rada pedagoga - praksa, teorija i zakonska regulativa. U M. Turk (ur.), Suvremeni izazovi u radu (školskog) pedagoga. Zbornik u čast Stjepana Staničića (str. 292-308). Filozofski fakultet u Rijeci. https://www.bib.irb.hr/865455

42. Pravilnik o tjednim radnim obvezama učitelja i stručnih suradnika u osnovnoj školi (2014). Narodne novine, 34/2014. https://narodne-novine.nn.hr/clanci/sluzbeni/2014_03_34_613.html 
43. Raine, G. (2007). Commercial activities in primary schools: a quantitative study. Oxford Review of Education, 33(2), 211-231. https://doi. org/10.1080/03054980701324552

44. Skopljak, M., Mihajlović, T. i Kovačević J. (2020). Uloge i zajedničke aktivnosti pedagoga i psihologa u školama. DHS, 4(13), 303-320. https://www.researchgate.net/publication/346680879_ULOGE_I_ZAJEDNICKE_AKTIVNOSTI_ PEDAGOGA_I_PSIHOLOGA_U_SKOLAMA

45. Štefulj, L. (2021). Utiliziranje resursa lokalne zajednice u suradnji školskoga pedagoga s obiteljima [diplomski rad. Filozofski fakultet Sveučilišta u Zagrebu]. https://repozitorij.ffzg.unizg.hr/en/islandora/object/ffzg\%3A3908

46. Turk, M. (ur.) (2017). Suvremeni izazovi u radu (školskog) pedagoga. Zbornik u čast Stjepana Staničića. Filozofski fakultet u Rijeci. https://www.bib.irb.hr/865455

47. Velki, T. i Ozdanovac, K. (2014). Preventivni programi usmjereni na smanjenje vršnjačkog nasilja u osnovnim školama na području Osječko-baranjske županije. Školski vjesnik: časopis za pedagogijsku teoriju i praksu, 63(3), 327-352. https:// hrcak.srce.hr/136069

48. Vračar, M. i Maksimović, A. (2017). Perspektiva pedagoga: kompetencije potrebne za uspješno profesionalno djelovanje. U M. Turk (ur.), Suvremeni izazovi u radu (školskog) pedagoga. Zbornik u čast Stjepana Staničića (str. 214-235). Filozofski fakultet u Rijeci. https://www.bib.irb.hr/865455

49. Walsh, M. E. i DePaul, J. (2008). The Essential Role of School-Community Partnerships In School Counseling. U H. L. K. Coleman i C. Yeh (ur.), Handbook of School Counseling (str. 765-783). Routledge. DOI: 10.4324/9780203874806

50. Zakon o odgoju i obrazovanju u osnovnoj i srednjoj školi (2008). Narodne novine, $87 / 2008$.

51. Zembylas, M. (2020). Affirmative critique as a practice of responding to the impasse between post-truth and negative critique: pedagogical implications for schools. Critical Studies in Education, 1-16. https://doi.org/10.1080/17508487.2 020.1723666

52. Žužić, S. i Markušić, P. (2017). Percepcija profesionalnog statusa i ugleda pedagoga. U M. Turk (ur.), Suvremeni izazovi u radu (školskog) pedagoga. Zbornik u čast Stjepana Staničića (str. 156-176). Filozofski fakultet u Rijeci. https://www. bib.irb.hr/865455 